\title{
Synthesis, characterization and antimicrobial activity of some new Oxadiazole derivatives in DMSO and DMF
}

\author{
Shipra Baluja ${ }^{a *}$, Sumitra Chanda ${ }^{b}$, Paras Ramavat $^{a}$ \\ ${ }^{a}$ Chemistry Department, 'Department of Biosciences, \\ Saurashtra University, Rajkot-360005 (Gujarat), India. \\ E-mail address: shipra_baluja@rediffmail.com
}

Keywords: Oxadiazole derivatives, DMSO, DMF, Gram positive bacteria, Gram negative bacteria, fungal strains.

ABSTRACT. A series of oxadiazole derivatives were synthesized and were characterized by IR, ${ }^{1} \mathrm{H}$ NMR and mass spectroscopy. All these synthesized compounds were tested for in vitro antimicrobial against four Gram positive bacteria, four Gram negative bacteria and four fungal strains in DMSO and DMF.

\section{INTRODUCTION}

Oxadiazoles are five membered cyclic derivatives containing two nitrogen and one oxygen atoms. There are four possible isomers of oxadiazoles; 1,2,4-oxadiazole (I), 1,2,5-oxadiazole (II), 1,2,3-oxadiazole (III) and 1,3,4-oxadiazole (IV), depending on the position of nitrogen atom in the ring. Oxadiazole framework is often encountered in compounds dealing with biological properties, such as antimicrobial [1-3], anti-inflamatory [4, 5], anticancer [6, 7], antioxidant [8], etc.

In the present paper, some new 1, 3, 4-oxadiazole derivatives are synthesized and their characterization was done by IR, ${ }^{1} \mathrm{H}$ NMR and mass spectral analysis.

The antimicrobial activity of the synthesized compounds was studied against some pathogenic Gram positive, Gram negative bacteria and fungi in DMSO and DMF.

\section{EXPERIMENTAL SECTION}

Synthesis of Ethyl 2-aminothiazole-5-carboxylate: Equimolar mixture of ethyl chloroacetate and ethyl formate was added drop wise to a suspension of sodium ethoxide solution $(0.01 \mathrm{M})$ in dry toluene at $0-5^{\circ} \mathrm{C}$. The reaction mixture was then stirred at $0^{\circ} \mathrm{C}$ for about $2-3 \mathrm{hr}$. The contents were diluted with water and the layers were separated. The aqueous phase was acidified with concentrated hydrochloric acid and to this acidified solution, 0.013 mole of aqueous thio urea solution was added. This solution was refluxed for $2.5 \mathrm{hr}$. The completion of reaction was confirmed by analytical thin layer chromatography (TLC) using (100\% Ethyl acetate) as mobile phase. After completion of reaction, the reaction mass was cooled and was neutralized with sodium hydroxide solution. An amber colored solid was precipitated which was filtered, air dried to get desired product ethyl 2-aminothiazole-5-carboxylate.
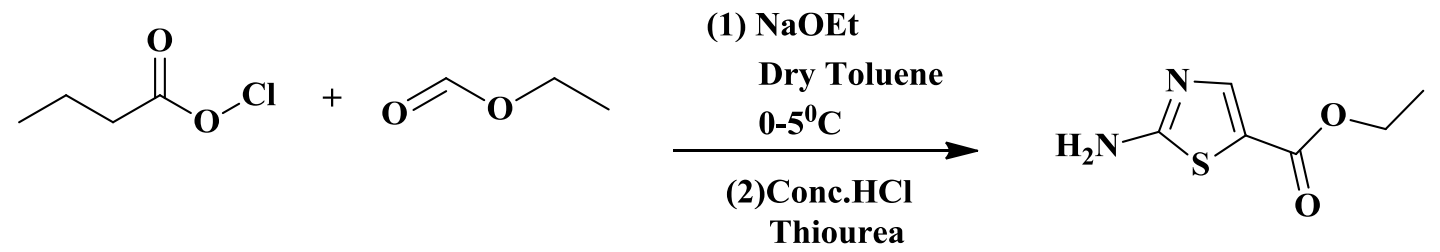

Synthesis of 5-(2-aminothiazol-5-yl)-1,3,4-oxadiazole-2-thiol: To a methanolic solution of Ethyl 2-aminothiazole-5-carboxylate $(0.01 \mathrm{M})$ at $0^{\circ} \mathrm{C}$, hydrazine hydrate $(0.01 \mathrm{M})$ was added and the solution was stirred for about $16 \mathrm{hr}$. The completion of reaction was confirmed by analytical thin layer chromatography (TLC) using (0.6:0.4 hexane : ethyl acetate) as mobile phase. After the completion of reaction, the reaction mass was filtered off and dried. The product is dissolved in methanol and carbon disulphide $(0.015 \mathrm{~mol})$ and $\mathrm{KOH}$ (catalytic amount) were added at $0^{\circ} \mathrm{C}$. The 
reaction mixture was then refluxed until the evolution of $\mathrm{H}_{2} \mathrm{~S}$ gas ceased (about $12 \mathrm{~h}$ ). The residue was dissolved in water and was acidified with $10 \%$ dilute hydrochloric acid. The resulting precipitate was filtered, dried, and crystallized from methanol. The completion of reaction was monitored by Thin Layer Chromatography.<smiles>CCOC(=O)c1cnc(N)s1</smiles><smiles>NNC(=O)c1cnc(N)s1</smiles>

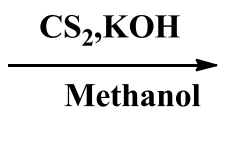<smiles>Nc1ncc(-c2nnc(S)o2)s1</smiles>

General synthesis of 2-((5-(2-aminothiazol-5-yl)-1,3,4-oxadiazol-2-yl)thio)-1-phenylethanone: A mixture of 5-(2-aminothiazol-5-yl)-1,3,4-oxadiazole-2-thiol $(0.01 \mathrm{~mol})$, different substituted phenacyl bromide $(0.012 \mathrm{~mole})$ and $10 \%$ aqueous solution of 1,4-diazabicyclo [2.2.2] octane (DABCO) was refluxed for $1 \mathrm{hr}$. The completion of reaction was confirmed by analytical thin layer chromatography (TLC) using (0.8:0.2-Hexane: Ethyl acetate) as mobile phase. After completion of reaction, the reaction mixture was cooled. The resulting solid was filtered, washed with cold water and dried under vacuum to get the crude product. The obtained crude product was purified by tituration with mixture of methanol and ethyl acetate.<smiles>Nc1ncc(-c2nnc(S)o2)s1</smiles><smiles>[R]c1ccc(C(=O)CBr)cc1</smiles><smiles>[R]c1cccc(C(=O)CSc2nnc(-c3cnc(N)s3)o2)c1</smiles>

RPG-1 to RPG-10 $R=$ different substitution

Structure Confirmation: The structures of these synthesized crystallized compounds were confirmed by FTIR, ${ }^{1} \mathrm{H}$ NMR and mass spectral data. IR spectra were recorded on IRaffinity $1 \mathrm{~S}$ (furrier transport infra-red spectroscopy), ${ }^{1} \mathrm{H}-\mathrm{NMR}$ spectra were taken on a Bruker AVANCE II 400 using DMSO- $\mathrm{d}_{6}$. Mass spectra were determined using direct inlet probe on a GCMS-QP-2010 mass spectrometer.

\section{ANTIMICROBIAL ACTIVITY}

Preparation of solutions of compounds:

For all the compounds, DMSO and DMF were used for screening of antimicrobial activity. The solution of $20 \mathrm{mg} / \mathrm{ml}$ concentration was prepared for all the compounds.

Microorganisms tested: The studied microorganisms were obtained from National Chemical Laboratory (NCL), Pune, India. The microorganisms were maintained at $4{ }^{\circ} \mathrm{C}$. The Gram positive bacteria studied were Bacilluscereus ATCC11778 (BC); Staphylococcusaureus ATCC29737 (SA), Corynebacteriumrubrum ATCC14898 (CR), Listeria monocytogenes ATCC19112 (LM), Gram negative bacteria were Escherichia coli NCIM2931 (EC), Pseudomonas aeruginosa ATCC27853(PA), Salmonella typhimurium ATCC23564 (ST), Klebsiellapneumoniae NCIM2719 (KP) and fungal strains were Candida glabrata NCIM3448 (CG), Candida epicola NCIM3367 (CE), Candida albicans ATCC2091 (CA) and Cryptococcusneoformans NCIM3542 (CN). The microorganisms studied are clinically important ones causing several infections and food spoilage.

In vitro antimicrobial activity of the oxadiazole derivatives was studied against pathogenic microbial strains by the agar well diffusion method [9]. 


\section{RESULTS AND DISCUSSION}

Table 1 shows the physical parameters of all the synthesized compounds. The IR, NMR and mass spectra of a compound RPG-1 is shown in Figure 1, 2 and 3 respectively.

\section{Spectral data}

\section{RPG-1:}

IR $\left(\mathrm{cm}^{-1}\right)$ : 1685.79 (acyclic carbonyl str.), 1639.49 (-NH bend.), 1600.92 (Ar-C=C str.), 1469.76 (alkane C-H bending), 1305.81 (Ar-C-N str.), 1211.30 (C-O str.), 837.11 (p-di substituted aromatic ring). ${ }^{1} \boldsymbol{H}$ NMR (DMSO-d $\left.{ }_{6}\right) \boldsymbol{\delta}(\mathbf{p p m}): 5.115$ (2H, singlet, $\left.-\mathrm{CH}_{2}\right), 7.404-7.448$ (2H, triplet, Ar-CH), $3.819\left(1 \mathrm{H}\right.$, singlet, $\left.-\mathrm{OCH}_{3}\right), 7.664(1 \mathrm{H}$, singlet, $-\mathrm{CH}$ of thiazole ring $), 7.924\left(2 \mathrm{H}\right.$, singlet, $\left.-\mathrm{NH}_{2}\right)$, 8.135-8.170 (2H, doublet of doublet, Ar-CH). MS: $(\boldsymbol{m} / \mathbf{z})=336$.

\section{RPG-2:}

IR $\left(\mathrm{cm}^{-1}\right): 1674.21$ (acyclic carbonyl str.), 1637.56 (-NH bend.), 1600.92 (Ar-C=C str.), 1469.76 (alkane C-H bending), 1296.16 (Ar-C-N str.), 1215.15 (C-O str.), 840.96 (p-di substituted aromatic ring). ${ }^{1} \boldsymbol{H}$ NMR (DMSO-d $\left.{ }_{6}\right) \boldsymbol{\delta}(\mathbf{p p m}): 2.404$ (3H, singlet, $\left.-\mathrm{CH}_{3}\right), 5.116\left(2 \mathrm{H}\right.$, singlet, $\left.-\mathrm{CH}_{2}\right), 7.373-$ $7.392\left(2 \mathrm{H}\right.$, doublet, Ar-CH), $7.679\left(1 \mathrm{H}\right.$, singlet, $-\mathrm{CH}$ of thiazole ring), $7.906\left(2 \mathrm{H}\right.$, singlet, $\left.-\mathrm{NH}_{2}\right)$, 7.954-7.973 (2H, doublet, Ar-CH). MS: $(\boldsymbol{m} / \mathbf{z})=332$.

\section{RPG-3:}

IR $\left(\mathrm{cm}^{-1}\right)$ : 1674.21 (acyclic carbonyl str.), 1635.64 (-NH bend.), 1600.92 (Ar-C=C str.), 1469.76 (alkane C-H bending), 1321.24 (Ar-C-N str.), 1215.15 (C-O str.), 808.17 (p-di substituted aromatic ring). ${ }^{1} \boldsymbol{H}$ NMR (DMSO-d 6 ) $\boldsymbol{\delta}(\mathbf{p p m})$ : $5.113\left(2 \mathrm{H}\right.$, singlet, $\left.-\mathrm{CH}_{2}\right), 7.404-7.448$ (2H, doublet, Ar-CH), $7.664\left(1 \mathrm{H}\right.$, singlet, $-\mathrm{CH}$ of thiazole ring), $7.924\left(2 \mathrm{H}\right.$, singlet, $\left.-\mathrm{NH}_{2}\right), 8.101-8.1106(2 \mathrm{H}$, doublet, Ar$\mathrm{CH})$. MS: $(\boldsymbol{m} / z)=352$.

\section{RPG-4:}

IR $\left(\mathrm{cm}^{-1}\right)$ : 1674.21 (acyclic carbonyl str.), 1635.64 (-NH bend.), 1600.92 (Ar-C=C str.), 1469.76 (alkane C-H bending), 1321.24 (Ar-C-N str.), 1215.15 (C-O str.), 808.17 (p-di substituted aromatic ring). ${ }^{1} \boldsymbol{H}$ NMR (DMSO-d $)$ $\boldsymbol{\delta}(\mathbf{p p m}): 5.111\left(2 \mathrm{H}\right.$, singlet, $\left.-\mathrm{CH}_{2}\right), 7.406-7.416(2 \mathrm{H}$, doublet, Ar-CH), $7.664(1 \mathrm{H}$, singlet, $-\mathrm{CH}$ of thiazole ring $), 7.924\left(2 \mathrm{H}\right.$, singlet, $\left.-\mathrm{NH}_{2}\right), 7.942-7.948(2 \mathrm{H}$, doublet, Ar$\mathrm{CH})$. MS: $(\boldsymbol{m} / \mathbf{z})=363$.

\section{RPG-5:}

IR $\left(\mathbf{c m}^{-1}\right)$ : 1674.22 (acyclic carbonyl str.), 1635.63 (-NH bend.), 1600.91 (Ar-C=C str.), 1469.72 (alkane C-H bending), 1321.28 (Ar-C-N str.), 1215.10 (C-O str.). ${ }^{1} \boldsymbol{H}$ NMR (DMSO-d $)$ ) $\boldsymbol{\delta}$ (ppm) : $5.116\left(2 \mathrm{H}\right.$, singlet, $\left.-\mathrm{CH}_{2}\right), 7.408-7.425(2 \mathrm{H}$, doublet, Ar- $\mathrm{CH}), 7.684(1 \mathrm{H}$, singlet, $-\mathrm{CH}$ of thiazole ring), $7.925\left(2 \mathrm{H}\right.$, singlet, $\left.-\mathrm{NH}_{2}\right), 8.125-8.138(3 \mathrm{H}$, multiplet, Ar-CH). $\boldsymbol{M S}:(\boldsymbol{m} / \boldsymbol{z})=318$.

\section{RPG-6:}

IR $\left(\mathrm{cm}^{-1}\right)$ : 1680.00 (acyclic carbonyl str.), 1651.07 (-NH bend.), 1604.77 (Ar-C=C str.), 1473.62 (alkane C-H bending), 1361.74 (Ar-C-N str.), 1215.15 (C-O str.), 810.10 (p-di substituted aromatic ring). ${ }^{1} \boldsymbol{H}$ NMR (DMSO-d $)$ $\boldsymbol{\delta}(\mathbf{p p m})$ : 5.115 (2H, singlet, $\left.-\mathrm{CH}_{2}\right), 7.408-7.4419$ (2H, doublet, Ar$\mathrm{CH}), 7.666\left(1 \mathrm{H}\right.$, singlet, $-\mathrm{CH}$ of thiazole ring), $7.928\left(2 \mathrm{H}\right.$, singlet, $\left.-\mathrm{NH}_{2}\right), 8.104-8.119(2 \mathrm{H}$, doublet, Ar-CH). MS: $(\boldsymbol{m} / z)=398$.

\section{RPG-7:}

IR $\left(\mathrm{cm}^{-1}\right)$ : 1660.71 (acyclic carbonyl str.), 1652.04 (-NH bend.), 1604.75 (Ar-C=C str.), 1477.47 (alkane C-H bending), 1311.59 (Ar-C-N str.), 1259.52 (C-O str.), 831.32 (p-di substituted aromatic ring). ${ }^{1} \boldsymbol{H}$ NMR (DMSO-d $)$ $\boldsymbol{\delta}(\mathbf{p p m}): 3.818\left(3 \mathrm{H}\right.$, singlet, $\left.-\mathrm{OCH}_{3}\right), 5.118\left(2 \mathrm{H}\right.$, singlet, $\left.-\mathrm{CH}_{2}\right), 7.378$ $7.398(2 \mathrm{H}$, doublet, Ar- $\mathrm{CH}), 7.688\left(1 \mathrm{H}\right.$, singlet, $-\mathrm{CH}$ of thiazole ring), $7.915\left(2 \mathrm{H}\right.$, singlet, $\left.-\mathrm{NH}_{2}\right)$, 8.023-8.102 (2H, doublet, Ar-CH). MS: $(\boldsymbol{m} / \mathbf{z})=348$.

\section{RPG-8:}

IR (cm $\left.{ }^{-1}\right): 1660.83$ (acyclic carbonyl str.), 1658.04 (-NH bend.), 1604.72 (Ar-C=C str.), 1477.40 (alkane C-H bending), 1311.50 (Ar-C-N str.), 1259.51 (C-O str.).

${ }^{1} \boldsymbol{H}$ NMR (DMSO-d $)$ o(ppm) : $2.408\left(3 \mathrm{H}\right.$, singlet, $\left.-\mathrm{CH}_{3}\right), 5.115\left(2 \mathrm{H}\right.$, singlet, $\left.-\mathrm{CH}_{2}\right)$, 7.456-7.460 $\left(2 \mathrm{H}\right.$, doublet, Ar-CH), $7.685(1 \mathrm{H}$, singlet, $-\mathrm{CH}$ of thiazole ring $), 7.926\left(2 \mathrm{H}\right.$, singlet, $\left.-\mathrm{NH}_{2}\right), 8.024-$ 8.108 (2H, multiplet, Ar-CH). MS: $(\boldsymbol{m} / z)=332$. 
RPG-9:

IR $\left(\mathrm{cm}^{-1}\right)$ : 1660.71 (acyclic carbonyl str.), 1652.04 (-NH bend.), 1604.65 (Ar-C=C str.), 1477.27 (alkane C-H bending), 1311.49 (Ar-C-N str.), 1259.34 (C-O str.).

${ }^{1} \boldsymbol{H}$ NMR (DMSO-d $)$ o(ppm) : 5.105 (2H, singlet, $\left.-\mathrm{CH}_{2}\right), 7.302(1 \mathrm{H}$, singlet, Ar-CH), 7.656 (1H, singlet, $-\mathrm{CH}$ of thiazole ring), $7.921\left(2 \mathrm{H}\right.$, singlet, $\left.-\mathrm{NH}_{2}\right), 8.115-8.204(2 \mathrm{H}$, doublet, Ar-CH), 8.217$8.229(1 \mathrm{H}$, multiplet, Ar-CH). MS: $(\boldsymbol{m} / z)=352$.

\section{RPG-10:}

IR $\left(\mathrm{cm}^{-1}\right)$ : 1660.11 (acyclic carbonyl str.), 1652.54 (-NH bend.), 1604.25 (Ar-C=C str.), 1477.77 (alkane C-H bending), 1311.29 (Ar-C-N str.), 1259.72 (C-O str.).

${ }^{1} \boldsymbol{H}$ NMR (DMSO-d $)$ $\boldsymbol{\delta}(\mathbf{p p m}): 5.102\left(2 \mathrm{H}\right.$, singlet, $\left.-\mathrm{CH}_{2}\right), 7.301$ (1H, singlet, Ar-CH), 7.645 (1H, singlet, $-\mathrm{CH}$ of thiazole ring), $7.911\left(2 \mathrm{H}\right.$, singlet, $\left.-\mathrm{NH}_{2}\right), 8.105-8.116(2 \mathrm{H}$, doublet, $\mathrm{Ar}-\mathrm{CH}), 8.212-$ $8.221(1 \mathrm{H}$, multiplet, Ar-CH). MS: $(\boldsymbol{m} / z)=363$.

\section{ANTIMICROBIAL ACTIVITY}

Figure 4 shows the zone of inhibition for the studied compounds against Gram positive bacteria in DMF. It is evident from figure 4 that in DMF against BC, only RPG-4 and RPG-10 showed inhibition. Other compounds had no effect at all. Against CR, only RPG-3 exhibited inhibition. This strain is not affected by other compounds. However, SA and LM are not affected by any of these synthesized compounds.

In DMSO, none of the compound was found to be effective against any of the selected four Gram positive bacteria. Thus, inhibition depends on solvent, structure of compound and bacterial strain. As evident from Table 1 that RPG-4 contains 4-nitro group whereas RPG-10 contains 3-nitro group. Thus, $\mathrm{BC}$ strain is inhibited only by the compounds containing nitro groups. Other groups had no effect on this strain. However, CR strain is inhibited by only 4-chloro substitution (as in RPG-3). RPG-9 also contains chloro group but this compound had no effect. This suggests that position of group is also responsible for the antimicrobial inhibition.

Thus, SA and LM are most resistant Gram positive bacteria and DMF is good solvent for the studied compounds against these Gram positive bacteria.

Figure 5 shows the zone of inhibition for the studied compounds against Gram negative bacteria in DMSO and DMF. In DMSO, there is no inhibition against EC, ST and KP by the studied compounds. Only against PA, some of the compounds exhibited inhibition and it is maximum for RPG-10. Minimum inhibition is shown by RPG-5. Thus, 3-nitro group (as in RPG-10) is again highly effective for PA and when there is no substitution in aryl ring ( as in RPG-5), minimum inhibition is observed. The compounds RPG-1, RPG-7, RPG-8 and RPG-9 could not affect PA.

In DMF (Figure 5[B]), against EC, only RPG-2, RPG-4 and RPG-5 exhibited inhibition. The compounds RPG-2 and RPG-4 contain 4-methyl and 4-nitro groups respectively which are found to be effective. However, the compounds RPG-8 and RPG-10 containing these groups but at 2- and 3-positions are not effective at all against EC. This again proves that position of group plays an important role in inhibition. RPG-5 containing aryl ring with no substitution shows highest inhibition against EC. The studied compounds could not inhibit PA and KP. ST is inhibited by all the compounds except RPG-3, RPG-4, RPG-6 and RPG-9 and it is maximum for RPG-1 containing 4-fluoro group. Thus, for Gram negative bacteria also, DMF is proved to be good solvent.

Figure 6 shows the inhibition for the studied compounds against fungal strains in DMSO and DMF. As evident from figure $6[\mathrm{~A}]$ that in DMSO against $\mathrm{CG}, \mathrm{CE}$ and $\mathrm{CN}$, only compound RPG-5 without substitution is found to be effective. However, against CA, RPG-8 and RPG-10 containing 2-methyl and 3-nitro groups are found to be effective.

In DMF (figure 6[B]) except RPG-9 and RPG-10, all compounds exhibited inhibition against $\mathrm{CG}$ and maximum is observed for RPG-5. None of the compounds are found to be effective against $\mathrm{CE}$ and $\mathrm{CN}$. The compounds RPG-1 and RPG-10 having 4-fluoro and 3-nitro groups respectively could inhibit $\mathrm{CA}$.

For the fungal strains also, DMF is good solvent and $\mathrm{CE}$ and $\mathrm{CN}$ are most resistant strains. 
Table 1. The physical constants of all the synthesized compounds

\begin{tabular}{|c|c|c|c|c|c|}
\hline $\begin{array}{c}\text { Compound } \\
\text { Code }\end{array}$ & Substitution R & M.F. & M.W. & $\begin{array}{c}\text { Yield } \\
\text { (\%) }\end{array}$ & $\boldsymbol{R}_{\boldsymbol{f}}^{*}$ value \\
\hline RPG-1 & $4-\mathrm{F}$ & $\mathrm{C}_{13} \mathrm{H}_{9} \mathrm{FN}_{4} \mathrm{O}_{2} \mathrm{~S}_{2}$ & 336 & 72 & 0.62 \\
\hline RPG-2 & $4-\mathrm{Me}$ & $\mathrm{C}_{14} \mathrm{H}_{12} \mathrm{~N}_{4} \mathrm{O}_{2} \mathrm{~S}_{2}$ & 332 & 75 & 0.64 \\
\hline RPG-3 & $4-\mathrm{Cl}$ & $\mathrm{C}_{13} \mathrm{H}_{9} \mathrm{ClN}_{4} \mathrm{O}_{2} \mathrm{~S}_{2}$ & 352 & 64 & 0.62 \\
\hline RPG-4 & $4-\mathrm{NO}_{2}$ & $\mathrm{C}_{13} \mathrm{H}_{9} \mathrm{~N}_{5} \mathrm{O}_{4} \mathrm{~S}_{2}$ & 363 & 68 & 0.63 \\
\hline RPG-5 & $-\mathrm{H}$ & $\mathrm{C}_{13} \mathrm{H}_{10} \mathrm{~N}_{4} \mathrm{O}_{2} \mathrm{~S}_{2}$ & 318 & 72 & 0.63 \\
\hline RPG-6 & $4-\mathrm{Br}$ & $\mathrm{C}_{13} \mathrm{H}_{9} \mathrm{BrN}_{4} \mathrm{O}_{2} \mathrm{~S}_{2}$ & 398 & 70 & 0.62 \\
\hline RPG-7 & $4-\mathrm{OCH}$ & $\mathrm{C}_{14} \mathrm{H}_{12} \mathrm{~N}_{4} \mathrm{O}_{3} \mathrm{~S}_{2}$ & 348 & 63 & 0.64 \\
\hline RPG-8 & $2-\mathrm{Me}$ & $\mathrm{C}_{14} \mathrm{H}_{12} \mathrm{~N}_{4} \mathrm{O}_{2} \mathrm{~S}_{2}$ & 332 & 78 & 0.63 \\
\hline RPG-9 & $3-\mathrm{Cl}$ & $\mathrm{C}_{13} \mathrm{H}_{9} \mathrm{ClN}_{4} \mathrm{O}_{2} \mathrm{~S}_{2}$ & 352 & 74 & 0.62 \\
\hline RPG-10 & $3-\mathrm{NO}_{2}$ & $\mathrm{C}_{13} \mathrm{H}_{9} \mathrm{~N}_{5} \mathrm{O}_{4} \mathrm{~S}_{2}$ & 363 & 71 & 0.63 \\
\hline
\end{tabular}

*0.8:0.2-Hexane: Ethyl acetate

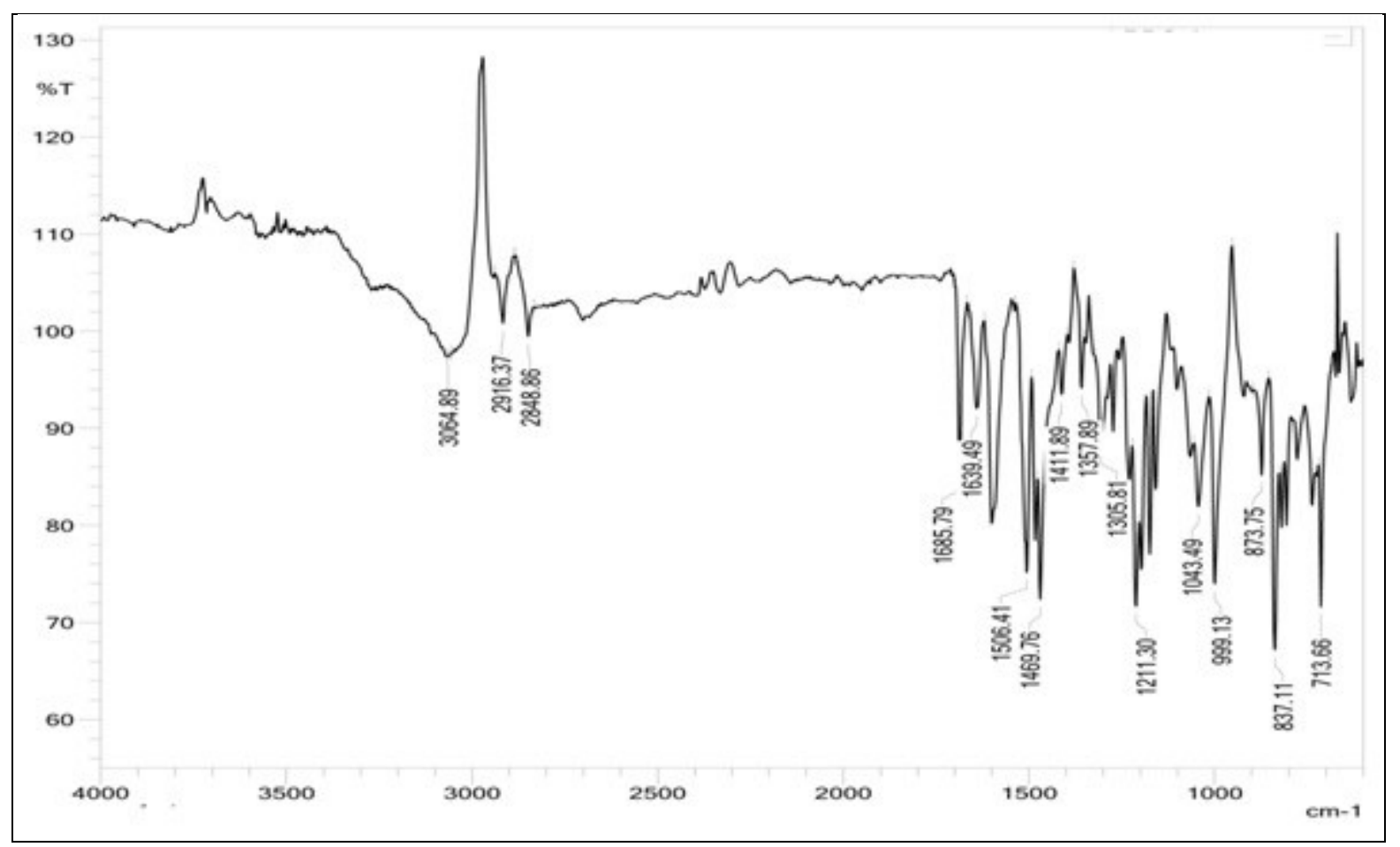

Figure 1. IR spectrum of compound RPG-1 


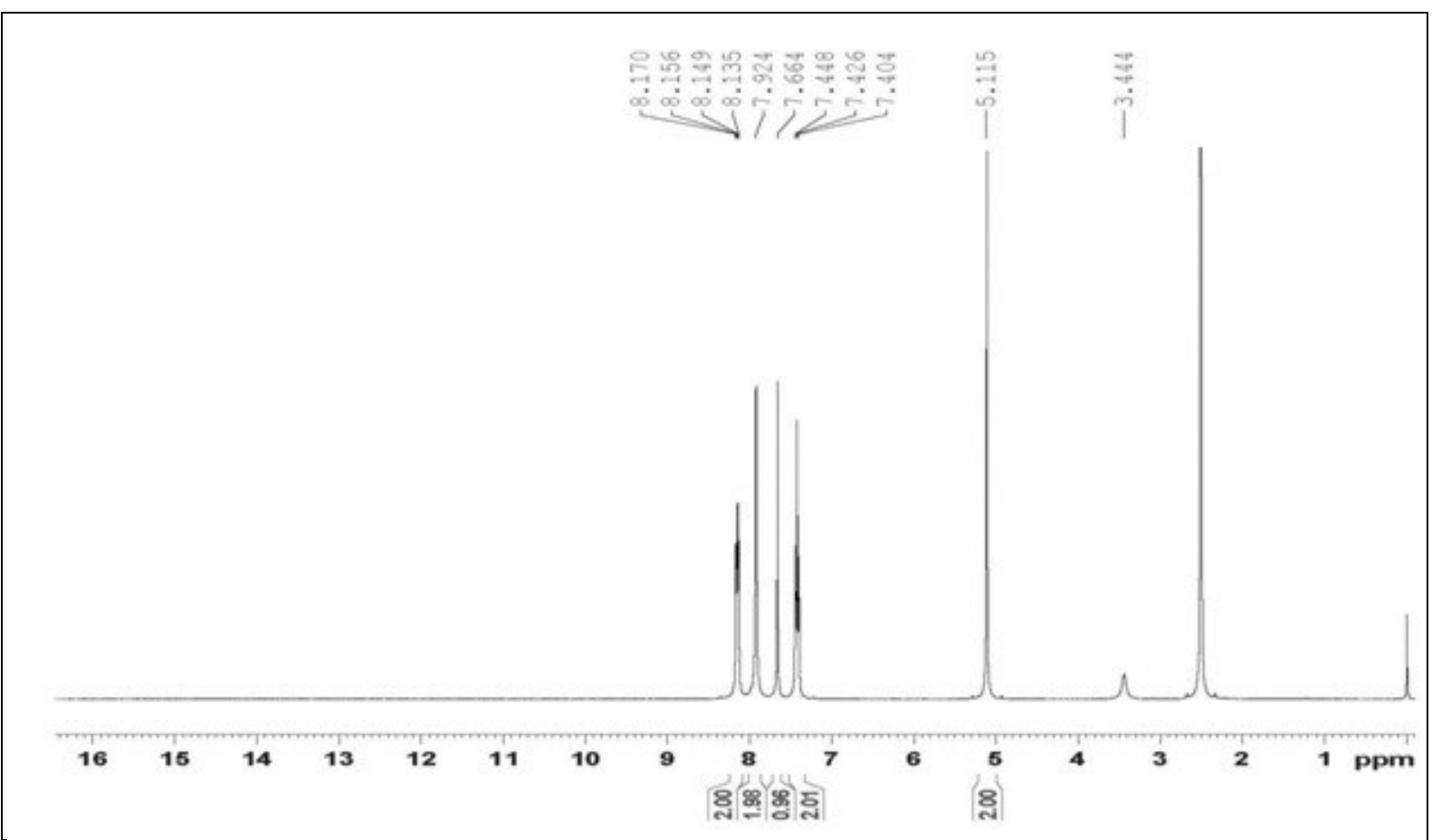

Figure 2. ${ }^{1} \mathrm{H}$ NMR spectrum of compound RPG-1

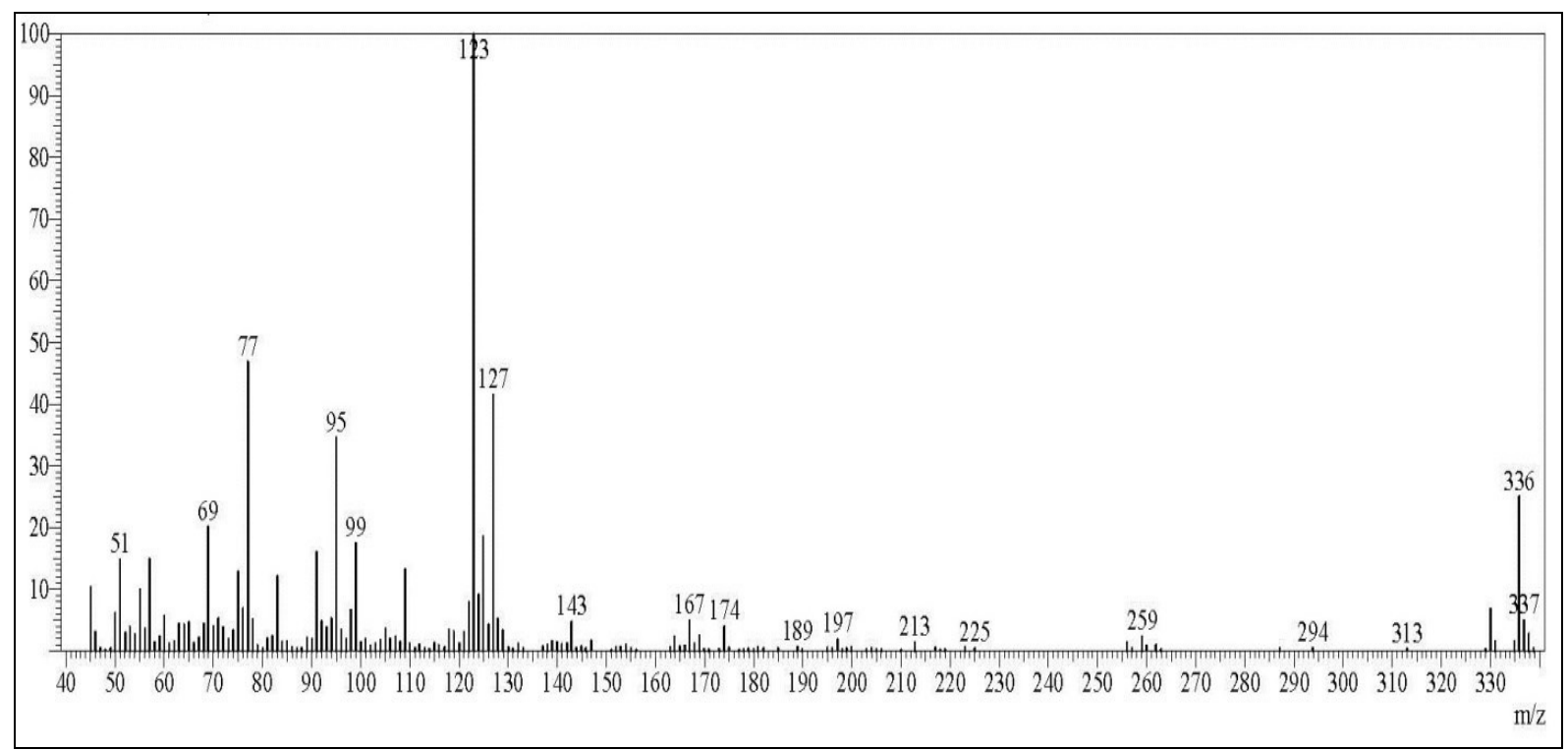

Figure 3. Mass spectrum of compound RPG-1 


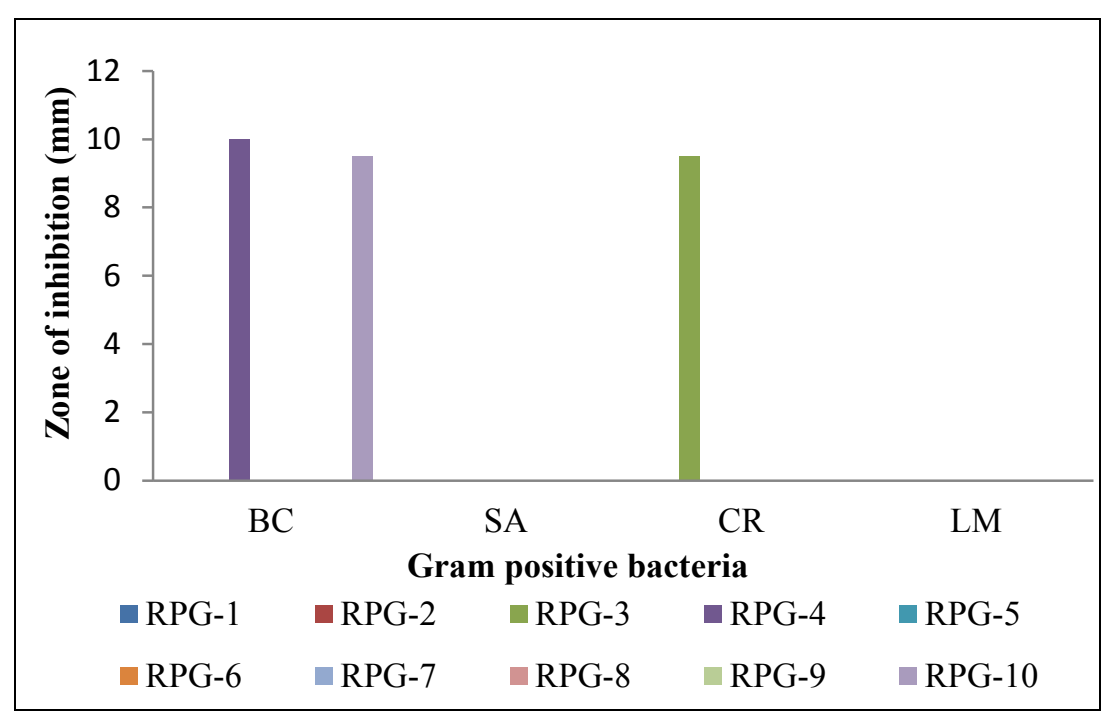

Figure 4. Antimicrobial activity of RPG-1 to RPG-10 against Gram positive bacteria in DMF
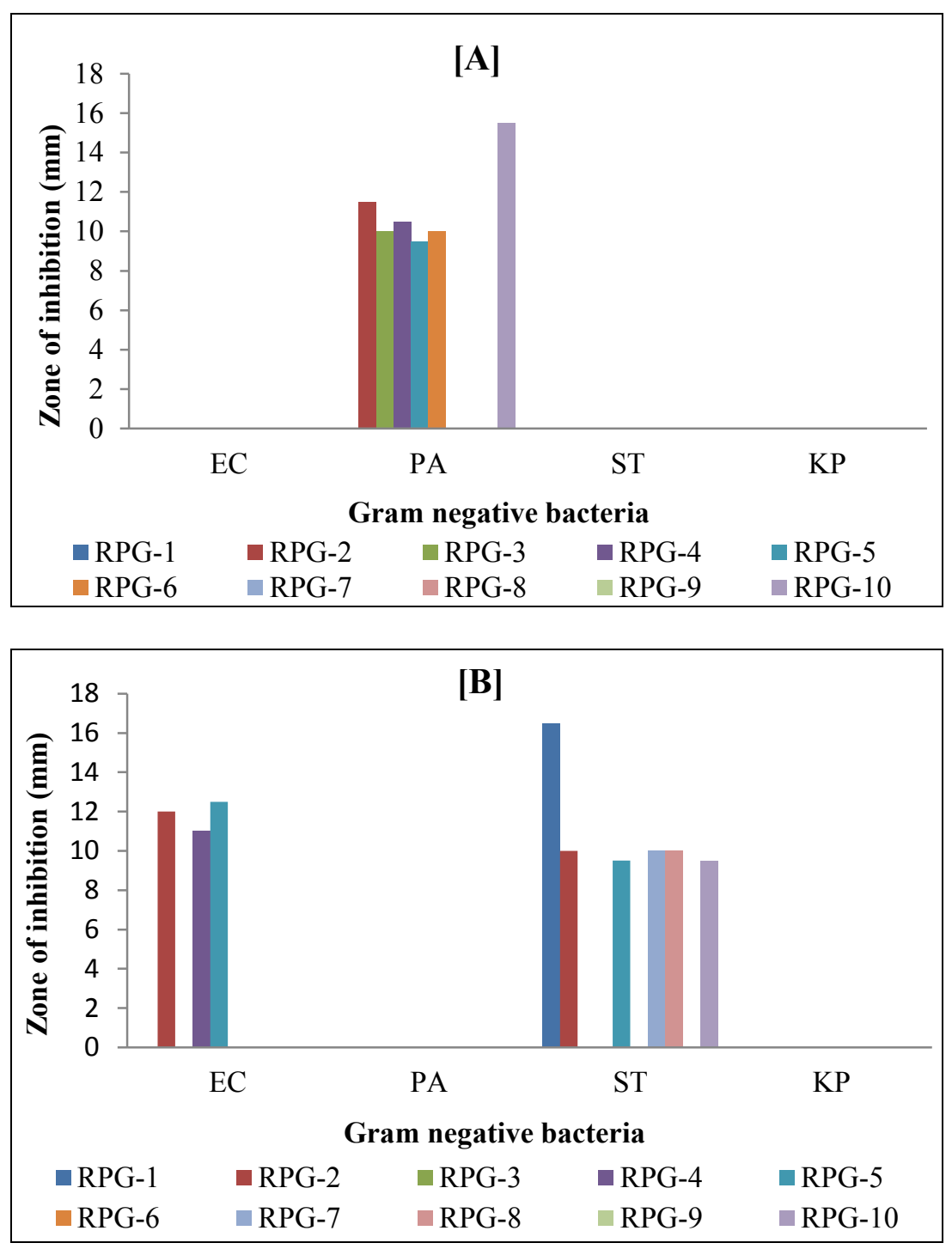

Figure 5. Antimicrobial activity of RPG-1 to RPG-10 against Gram negative bacteria [A] DMSO and $[\mathrm{B}] \mathrm{DMF}$ 

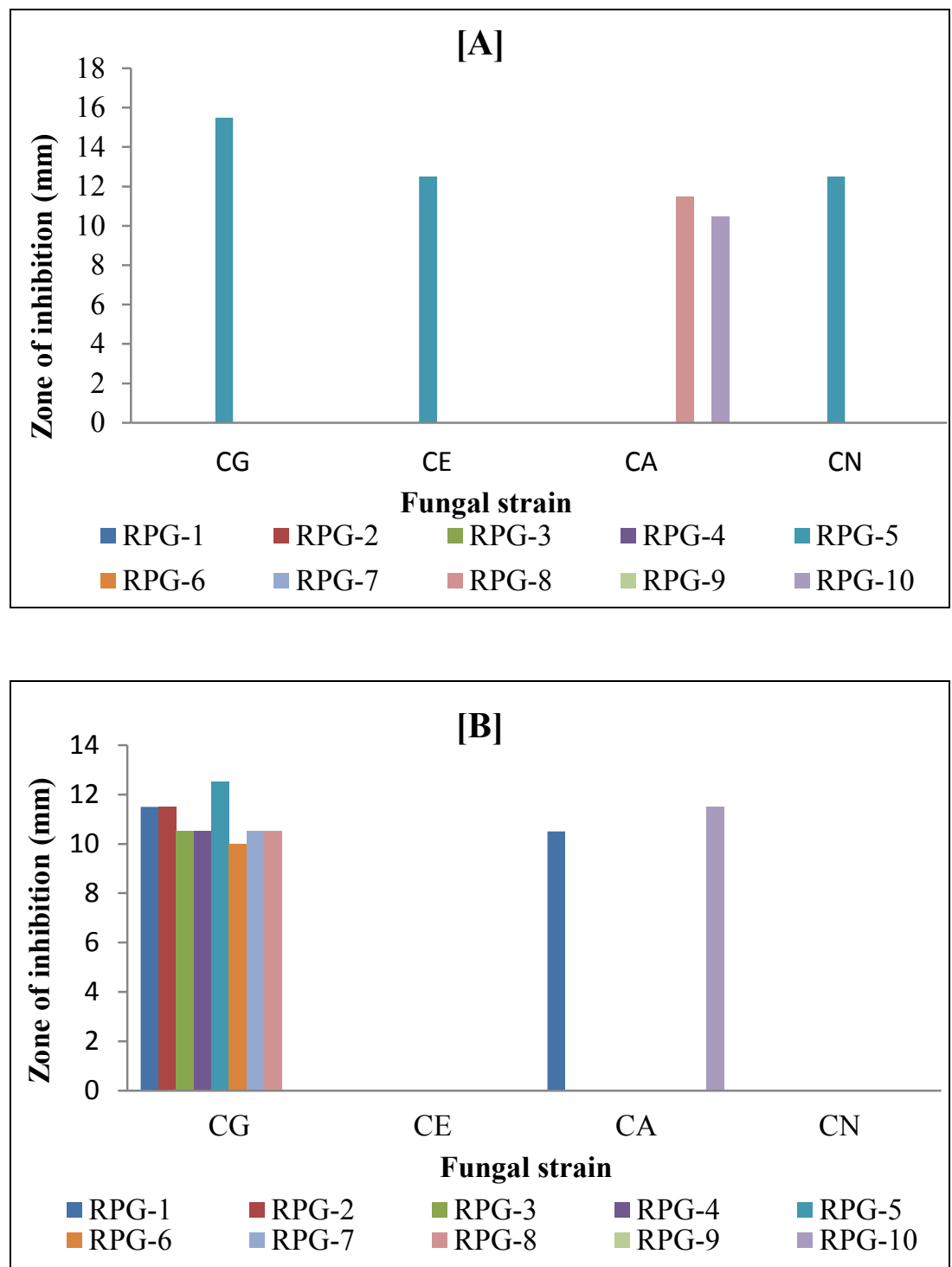

Figure 6. Antimicrobial activity of RPG-1 to RPG-10 against Fungal strains [A] DMSO and [B]

DMF

\section{CONCLUSION}

Thus, it is also concluded that inhibition depends on solvent, structure and strain. Further, position of different groups also affects inhibition. For the studied Gram positive bacteria, nitro group is most effective. For studied antimicrobial activity, DMF is found to be good solvent. Among the studied bacterial and fungal strains, SA, LM, KP, CE and CN are most resistant strains.

\section{Acknowledgement}

Authors are thankful to Head of Chemistry Department for providing necessary facilities.

\section{References}

[1] S. N. Bhardwaj, S. K. Saraf, P. Sharma, P. Kumar, Syntheses, evaluation and characterization of some 1, 3, 4-oxadiazoles as antimicrobial agents, Eur. J. Chem., 6 (2009) 1133-1138.

[2] M. A. A. Omar, Synthesis and antimicrobial activity of new 5-(2- thienyl)-1,2,4-triazoles and 5(2-thienyl)-1,3,4-oxadiazoles and related derivatives, Molecules., 15 (2010) 502-514.

[3] A. Rathavi, M. Shukla, M. K. Thakor, Design, synthesis and antimicrobial screening of Striazinyl derivatives containing 1,3,4-oxadiazole ring, Archives of Applied Science Research, 6 (2014) 82-89. 
[4] A. Kumar, S. Singh, M. Verma, A. K. Saxena, K. Shanker, Potent anti-inflammatory 2-(ohydroxyphenyl)-5-(p-dimethylaminophenyl)-1,3,4-oxadiazoles, Ind. J. Pharm. Sci., 49 (1987) 201-204.

[5] M. M. Burbuliene, V. Jakubkiene, G. Mekuskiene, E. Udrenaite, R. Smicius, P. Vainilavicius, Synthesis and anti-inflammatory activity of derivatives of 5-[(2-disubstitutedamino-6methylpyrimidin-4-yl)-sulfanylmethyl]-3H-1,3,4-oxadiazole-2-thiones, IL Farmaco., 59 (2004) 767-773.

[6] A. H. Samir, A. H. Jawad, Z. M. Malik, Al-Rubaei, In vitro study of the effect of some prepared oxadiazole derivatives on ALP, AST and ALT activities in sera of hepatocellular cancer patients and healthy control, Journal of Al-Nahrain University, 13 (2010) 76-81.

[7] E. D. Chrysina, M. N. Kosmopoulou, C. Tiraidis, R. Kardakaris, N. Bischler, D. D. Leonidas, Z. Hadady, L. Somsak, T. Docsa, P. Gergely, N. G. Oikonomakos, Kinetic and crystallographic studies on 2-( $\beta$-D-glucopyranosyl-5-methyl- 1, 3, 4-oxadiazole, -benzothiazole, andbenzimidazole, inhibitors of muscle glycogen phosphorylase b. Evidence for a new binding site. Protein Sci., 14, (2005) 873-888.

[8] P. Patrao, A. M. A. Khader, B. Kalluray, Vinayachandra, Synthesis of new 5-naphthyl substituted 1,3,4-oxadiazole derivatives and their antioxidant activity, Der Pharma Chemica, 5 (2013) 24-32.

[9] J. Parekh, P. Inamdhar, R. Nair, S. Baluja, S. Chanda, Synthesis and antibacterial activity of some Schiff bases derived from 4-aminobenzoic acid, J. Serb. Chem. Soc., 70 (2005) 11551158. 